\title{
ОСОБЛИВОСТІ ФУНКЦІЙНОГО ВИЯВУ ПРИКМЕТНИКІВ, ЧИСЛІВНИКІВ, ЗАЙМЕННИКІВ І ПРИСЛІВНИКІВ У НАЗВАХ РОЗДІЛІВ І СТАТЕЙ КРИМІНАЛЬНОГО КОДЕКСУ УКРАЇНИ
}

Прадід О. Ю. Особливості функційного вияву прикметників, числівників, займенників і прислівників у назвах розділів і статей Кримінального кодексу України.

Стаття присвячена дослідженню особливостей функційного вияву прикметників, числівників, займенників і прислівників, ужитих у назвах розділів і статей Кримінального кодексу України. У статті зазначається, що найуживанішими в назвах розділів і статей кодексу є іменники і прикметники (співвідношення відповідно 5:1 і 3:1). Рідше фіксуються займенники, зовсім рідко - прислівники і числівники.

Ключові слова: назви розділів і статей Кримінального кодексу України, функційний вияв, прикметник, займенник, числівник, прислівник.

Прадид О. Ю. Особенности функционального проявления прилагательных, числительных, местоимений и наречий в названиях розделов и статей Уголовного кодекса Украины.

Статья посвящена исследованию особенностей функціонального проявления прилагательных, числительных, местоимений и наречий, ужитих в названиях разделов и статей Уголовного кодекса Украины. В статье отмечается, что наиболее употребительными в названиях разделов и статей кодекса являются существительные и прилагательные (соотношение соответственно 5:1 и 3:1). Реже фиксируются местоимения, совсем редко - наречия и числительные.

Ключевые слова: названия розделов и статей Уголовного кодекса Украины, функциональное проявление, прилагательное, числительное, местоимение, наречие.

Pradid O. J. Peculiarities of functional demonstration of adjectives, numbers, pronouns and adverbs in titles of divisions and articles of the Criminal Code of Ukraine.

The article is devoted to the study of peculiarities of functional demonstration of adjectives, numbers, pronouns and adverbs in titles of divisions and articles of the Criminal Code of Ukraine. It is noted that nouns and adjectives are the most used parts of speech (correlation correspondingly 5:1 and 3:1). Pronouns are seldom recorded, adverbs and numbers are very seldom recorded.

Key words: titles of divisions and articles of the Criminal Code of Ukraine, function, adjective, number, pronoun, adverb.

Дослідження мови і стилю законодавчих актів має важливе значення на етапі розбудови державності в Україні. Не випадково в кінці XX - на початку XXI ст. на сторінках наукових видань, філологічних і юридичних, дедалі частіше почали з'являтися праці 3 цієї проблематики, захищено понад два десятки дисертацій, об'єктом вивчення в яких є різноманітні аспекти як мови і стилю законодавства взагалі, так i окремих його галузей (див., наприклад, праці 
О. І. Білоусової [1], С. П. Кравченка [2], О. Ю. Прадід [3], В. Г. Рогожі [4], 3. А. Тростюк [5] та ін. учених). Проте поза увагою вчених досі залишається чимало проблем, зокрема детальний аналіз окремих законодавчих актів, законів і кодексів, результати якого могли б суттєво вплинути на удосконалення мови законодавства.

Мета пропонованої статі - дослідити функціональні вияви прикметників, числівників, займенників і прислівників, ужитих у назвах розділів і статей розділів і статей Кримінального кодексу України (далі ККУ).

Частотність використання прикметників у назвах розділів i статей ККУ є досить високою. За нашими підрахунками в кожній другій назві розділу, у трьох із чотирьох назвах статей ККУ наявні прикметникові форми.

Як свідчить аналіз, частіше вживаються відносні прикметники: Примусові заходи медичного характеру та примусове лікування (розділ ХІУ ЗЧ); Правові наслідки засудження особи за межами України (ст. 9); Вчинення злочину групою осіб, групою осіб за попередньою змовою, організованою групою або злочинною організацією (ст. 28); Фізичний або психічний примус (ст. 40); Позбавлення військового, спеціального звання, рангу, чину або кваліфікаційного класу (ст. 54) та ін.; набагато рідше - якісні: Загальні положення (розділ 1 ЗЧ); Призначення більш м'якого покарання, ніж передбачено законом (ст. 69); Умисне тяжке тілесне ушкодження (ст. 121); Грубе порушення законодавства про праџю (ст. 172); Порушення порядку ведення реєстру власників іменних цінних паперів (ст. 223-2) та ін.

Відносні прикметники, ужиті в назвах розділів і статей ККУ, найчастіше утворені за словотвірними моделями:

OІм. + -н-: Закон про кримінальну відповідальність (розділ II ЗЧ); Кримінальна відповідальність за злочини, вчинені у стані сп'яніння внаслідок вживання алкоголю, наркотичних засобів або іниих одурманюючих речовин (ст. 21); Уявна оборона (ст. 37); Крайня необхідність (ст. 39); Перешкоджання законній діяльності професійних спілок, політичних партій, громадських організачій (ст. 170) та ін.;

OІм. + -ов-: Правові наслідки засудження особи за межами Украӥни (ст. 9); Звільнення від кримінальної відповідальності у зв'язку з дійовим каяттям (ст. 45); Позбавлення військового, спеціального звання, рангу, чину або кваліфікаиійного класу (ст. 54); Службові обмеження для військовослужбовців (ст. 58); Застосування додаткових покарань у разі звільнення від відбування основного покарання з випробуванням (ст. 77);

OІм. + -ськ-(-цьк-): Злочини у сфері господарської діяльності ๑) О. Ю. Прадід, 2013. 
(розділ УІІ ОЧ); Дії, спрямовані на насильницьку зміну чи повалення конституційного ладу або на захоплення державної влади (ст. 109); Посягання на життя державного чи громадського діяча (ст. 112); Насильницьке донорство (ст. 144); Зловживання опікунськими правами (ст. 167); Порушення прав на винахід, корисну модель, промисловий зразок, топографію інтегральної мікросхеми, сорт рослин, раціоналізаторську пропозицію (ст. 177) та ін.,

рідше - за словотвірними моделями:

ОІм. + -ев-: Злочини проти статевої свободи та статевої недоторканості особи (розділ ІУ ОЧ); Злочини проти авторитету органів державної влади, органів місцевого самоврядування та об'єднань громадян (розділ ХУ ОЧ); Статеві зносини з особою, яка не досягла статевої зрілості (ст. 155); Незаконне заволодіння трунтовим покривом (поверхневим шаром) земель (ст. 239-1);

OІм. + -к-: Умисне заподіяння тяжких тілесних ушкоджень у разі перевищення меж необхідної оборони або у разі перевищення заходів, необхідних для затримання злочиния (ст. 124);

OІм. + -альн-: Посягання на територіальну цілісність $i$ недоторканність України (ст. 110); Порушення законодавства про континентальний шельф Украӥни (ст. 244);

OІм. + -ивн-: Фіктивне банкрутство (ст. 218); Порушення правил адміністративного нагляду (ст. 395);

OІм. + -ичн-: Незаконне поміщення в психіатричний заклад (ст. 151); Створення терористичної групи чи терористичної організації (ст. 258-3);

OІм. + -ч-: Злочини проти виборчих, трудових та інших особистих прав $i$ свобод людини $i$ громадянина (розділ У ОЧ); Фальсифікація виборчих документів, документів референдуму чи фальсифікація підсумків голосування, надання неправдивих відомостей до органів Державного реєстру вибориів чи фальсифікація відомостей Державного реєстру вибориів (ст. 158);

OІм. + -ітн-: Звільнення від відбування покарання вахітних жінок і жінок, які мають дітей віком до трьох років (ст. 83);

OІм. + -арн-: Тримання в дисциплінарному батальйоні військовослужбовців (ст. 62);

OІм. + -евн-: Умисне вбивство, вчинене в стані сильного душевного хвилювання (ст. 116);

OІм. + -ічн-: Приховування або перекручення відомостей про екологічний стан або захворюваність населення (ст. 238);

ОІм. + -ив-: Завідомо неправдиве повідомлення про вчинення 
злочину (ст. 383);

ОІм. + -ист-: Злочини проти виборчих, трудових та іниих особистих прав і свобод людини і громадянина (розділ У ОЧ).

Іноді відносні прикметники, ужиті в назвах статей ККУ, утворені за іншими словотвірними моделями:

ОІнф. + -н-: Незаконне використання знака для товарів $і$ послуг, фірмового найменування, кваліфікованого зазначення походження mовару (ст. 230);

ОПрисл. + -н-: Правила складання покарань та зарахування строку попереднього ув'язнення (ст. 72); Незаконне використання спеціальних технічних засобів негласного отримання інформациї (ст. 359);

ОПрисл. + -ш-: Недотримання особою обов'язкових умов щуодо приватизачії державного, комунального майна або підприємств та їх подальшого використання (ст. 235);

ОІм. + конф.: Злочини проти миру, безпеки людства та міжннародного правопорядку (розділ ХХ ОЧ); Безгосподарське використання земель (ст. 254); Порушення порядку здійснення міжннародних передач товарів, щ⿻ підлягають державному експортному контролю (ст. 333); Розголошення даних досудового слідства або дізнання (ст. 387);

ОІм. + ОД + суф.: Злочини у сфері використання електроннообчислювальних машин (комп'ютерів), систем та комп'ютерних мереж і мереж електрозв'язку (розділ ХУІ ОЧ); Недбале зберігання вогнепальної зброї або бойових припасів (ст. 264); Посів або вирочування снотворного маку чи конопель (ст. 310); Опір представникові влади, прачівникові правоохоронного органу, члену громадського формування з охорони громадського порядку $i$ державного кордону або військовослужбовцеві (ст. 342) та ін.;

ОП + ОІм. + суф.: Добровільна відмова при незакінченому злочині (ст. 17); Використання малолітньої дитини для заняття жебрацтввом (ст. 150-1); Порушення правил здачі дорогоцінних металів і дорогоцінного каміння (ст. 214); Випуск або реалізація недоброякісної продукиії (ст. 227);

ОПрисл. + ОД + суф.: Незаконне перевезення на повітряному судні вибухових або легкозаймистих речовин (ст. 269);

OІм. + суф. + OІм. + суф.: Злочини у сфері обігу наркотичних засобів, психотропних речовин, їх аналогів або прекурсорів та інші злочини проти здоров'я населення (розділ ХІІІ ОЧ); Видання нормативно-правових або розпорядчих актів, які змінюють доходи $i$ видатки бюджету всупереч встановленому законом порядку (ст. 211); 
Контрабанда наркотичних засобів, психотропних речовин, $\ddot{x}$ аналогів або прекурсорів (ст. 305).

Не дивно, що найчастіше в назвах розділів і статей ККУ вживаються прикметники незаконний (51 раз), кримінальний (23 рази).

У більшості назв розділів і статей ККУ використовуються конструкції з одним прикметником (відповідно 68,4% і (59,8 \%): Закон про кримінальну відповідальність (розділ II ЗЧ); Злочини проти основ національної безпеки України (розділ I ОЧ); Правові наслідки засудження особи за межами України (ст. 9); Довічне позбавлення волі (ст. 64); Загальні засади призначення покарання (ст. 65) та ін.

У кожній четвертій назві розділу і в кожній п'ятій назві статті вживаються два прикметники: Злочини проти авторитету органів держкавної влади, органів місцевого самоврядування та об'єднань громадян (розділ ХУ ОЧ); Злочини проти встановленого порядку несення військової служби (військові злочини) (розділ ХІХ ОЧ); Фізичний або психічний примус (ст. 40); Посягання на життя державного чи громадського діяча (ст. 112); Порушення порядку фінансування виборчої кампанії кандидата, політичної партії (блоку) (ст. 159-1) та ін.

Іноді в назвах розділів (1 раз) і статей (48 раз) ККУ використовуються три прикметники: Злочини проти виборчих, трудових та інших особистих прав і свобод людини $і$ громадянина (розділ У ОЧ); Позбавлення військового, спеціального звання, рангу, чину або кваліфікаційного класу (ст. 54); Дї, спрямовані на насильницьку зміну чи повалення конституційного ладу або на захоплення державної влади (ст. 109); Умисне тяжке тілесне ушкодження (ст. 121) та ін.

Чотири і більше прикметників вживаються лише в назвах статей ККУ, причому 16 разів - чотири прикметники: Необережне тяжке або середньої тяжкості тілесне ушкодження (ст. 128); Неналежне виконання професійних обов'язків медичним або фармацевтичним прачівником (ст. 140); Перешкоджання законній діяльності професійних спілок, політичних партій, громадських організацій (ст. 170); Порушення прав на винахід, корисну модель, промисловий зразок, топографію інтегральної мікросхеми, сорт рослин, раціоналізаторську пропозицію (ст. 177); Угон або захоплення залізничного рухомого складу, повітряного, морського чи річкового судна (ст. 278) та ін.; 2 рази - п'ять прикметників: Умисне тяжке тілесне ушкодження, заподіяне у стані сильного душевного хвилювання (ст. 123); Викрадення, привласнення, вимагання вогнепальної зброї, бойових припасів, вибухових речовин чи радіоактивних матеріалів або заволодіння ними шляхом шахрайства або зловжсиванням службовим становищем (ст. 262), а 1 раз - навіть сім 
прикметників: Викрадення, привласнення, вимагання військовослужбовцем зброї, бойових припасів, вибухових або інших бойових речовин, засобів пересування, військової та спеціальної техніки чи іншого військового майна, а також заволодіння ними шляхом шахрайства або зловживання службовим становищем (ст. 410).

Усього тричі в назвах статей ККУ вжито числівник (у назвах розділів він не фіксується), який називає точно окреслене абстрактноматематичне число: Звільнення від відбування покарання 3 випробуванням вагітних жінок і жінок, які мають дітей віком до семи років (ст. 79); Звільнення від відбування покарання вагітних жінок $i$ жінок, які мають дітей віком до трьох років (ст. 83); Голосування виборием на виборчій дільниці більше ніж один раз (ст. 158-1).

Використання займенникових форм, як свідчить аналіз, теж не $є$ типовим явищем для назв розділів і статей ККУ. Рідко в назвах статей кодексу, наприклад, особові займенники, а в назвах розділів вони взагалі відсутні: Привласнення, розтрата майна або заволодіння ним иляхом зловжсивання службовим становищем (ст. 191); Незаконне привласнення особою знайденого або чужого майна, що випадково опинилося у неї (ст. 193); Порушення правил експлуатаиії електронно-обчислювальних машин (комп'ютерів), автоматизованих систем, комп'ютерних мереж чи мереж електрозв'язку або порядку чи правил захисту інформації, яка в них оброблюється (ст. 363); Відмова свідка від давання показань або відмова експерта чи перекладача від виконання покладених на них обов'язків (ст. 385); Незаконне використання символіки Червоного Хреста і Червоного Півмісяия та зловжсивання ними (ст. 435) та ін.

Усього в назвах статей кодексу особові займенники я (мu), mu (ви), він (вона, воно, вони) вжито 15 разів.

Найчастіше в назвах розділів і статей кодексу вживаються присвійні займенники його (iï, $\ddot{\imath})$, зазвичай у родовому відмінку множини: Порушення рівноправності громадян залежно від їx расової, національної належності або релігійних переконань (ст. 161); Незаконні дії з документами на переказ, платіжними картками та іншими засобами доступу до банківських рахунків, обладнанням для їх виготовлення (ст. 200); Недотримання особою обов'язкових умов щзодо приватизаиії державного, комунального майна або підприємств та їх подальшого використання (ст. 235); Контрабанда наркотичних засобів, психотропних речовин, їх аналогів або прекурсорів (ст. 305); Посягання на життя суддi, народного засідателя чи присяжного у зв 'язку з їх діяльністю, пов 'язаною із здійсненням правосуддя (ст. 379) та ін., рідше - у родовому відмінку однини: Злочин, його види та ○) О. Ю. Прадід, 2013. 
стадії (розділ III ЗЧ); Вина та їі форми (розділ У ЗЧ); Умисел і його види (ст. 24); Викрадення електричної або теплової енергії иляхом ї̈ самовільного використання (ст. 188-1); Опір начальникові або примушування його до порушення службових обов'язків (ст. 404) та ін.

Усього в назвах розділів кодексу присвійні займенники його (ï̈, ïx) вжито 4 рази, у назвах статей - 22 рази.

Тричі в назвах статей ККУ фіксується присвійний займенник свій $($ своя, своє, своі), який вказує на належність предмета будь-якій особі, що є суб'єктом дії: Умисне вбивство матір ю своєї новонародженої дитини (ст. 117); Примушування працівника транспорту до невиконання своїх службових обов'язків (ст. 280); Неповідомлення капітаном назви свого судна при зіткненні суден (ст. 285).

Двічі в назвах розділів уживається означальний займенник інший (інша, інше, інші): Злочини проти виборчих, трудових та інших особистих прав і свобод людини і громадянина (розділ У ОЧ); Злочини у сфері обігу наркотичних засобів, психотропних речовин, їх аналогів або прекурсорів та інші злочини проти здоров'я населення (розділ ХІІІ ОЧ).

Частіше означальний займенник інший (інша, інше, інші) вживається в назвах статей кодексу: Кримінальна відповідальність за злочини, вчинені у стані сп'яніння внаслідок вживання алкоголю, наркотичних засобів або інших одурманюючих речовин (ст. 21); Зараження вірусом імунодефіциту людини чи іншої невиліковної інфекційної хвороби (ст. 130); Незаконні дї з документами на переказ, платіжними картками та іншими засобами доступу до банківських рахунків, обладнанням для їх виготовлення (ст. 200); Незаконне зайняття рибним, звіриним або іншим водним добувним промислом (ст. 249); Випуск в експлуатацію технічно несправних транспортних засобів або інше порушення їх експлуатащії (ст. 287) та ін.

Усього в назвах статей ККУ означальний займенник інший (інша, інше, інші) зафіксовано 17 разів, причому в ст. 410 двічі: Викрадення, привласнення, вимагання військовослужбовцем зброї, бойових припасів, вибухових або інших бойових речовин, засобів пересування, військової та спеціальної техніки чи іншого військового майна, а також заволодіння ними шляхом шахрайства або зловживання службовим становищем.

У всіх випадках і в назвах розділів, і в назвах статей кодексу означальний займенник інший (інша, інше, інші) вжито для відмежування означуваних предметів або явищ від уже відомих.

Чотири рази в назвах статей ККУ вживається вказівний займенник такий (така, таке, такі): Викрадення, привласнення, вимагання 
обладнання, призначеного для виготовлення наркотичних засобів, психотропних речовин або їх аналогів, чи заволодіння ним иляхом шахрайства або зловживання службовим становищем та інші незаконні дії з таким обладнанням (ст. 313); Несанкціоновані збут або розповсюдження інформачії з обмеженим доступом, яка зберігається 6 електронно-обчислювальних машинах (комп'ютерах), автоматизованих системах, комп'ютерних мережах або на носіях такої інформації (ст. 361-2); Несанкиіоновані дї з інформацією, яка оброблюється $в$ електронно-обчислювальних машинах (комп'ютерах), автоматизованих системах, комп'ютерних мережах або зберігається на носіях такої інформачії, вчинені особою, яка має право доступу до неї (ст. 362); Розголошення відомостей військового характеру, щуо становлять державну таємницю, або втрата документів чи матеріалів, щзо містять такі відомості (ст. 422), тричі - присвійний займенник свій (своя, своє): Умисне вбивство матір ю своєї новонародженої дитини (ст. 117); Примушування працівника транспорту до невиконання своӥх службових обов'язків (ст. 280); Неповідомлення капітаном назви свого судна при зіткненні суден (ст. 285).

Прислівник у назвах розділів ККУ не зафіксований, а в назвах статей уживається 11 разів, причому в 6 статтях використовується прислівник завідомо (калька рос. прислівника заведомо) замість українського відповідника свідомо: Завідомо неправдиве повідомлення про загрозу безпеці громадян, знищення чи пошкодження об'єктів власності (ст. 259); Завідомо незаконні затримання, привід, арешт або тримання під вартою (ст. 371); Притягнення завідомо невинного до кримінальної відповідальності (ст. 372) та ін. У всіх випадках прислівник завідомо поєднується 3 прикметником і виражає якісну ознаку іншої ознаки.

По разу в назвах статей ККУ вживаються означальні прислівники випадково, незаконно, особливо, технічно, радіоактивно.

Якісно-означальний прислівник випадково поєднується з дієсловом і виражає якісну характеристику дії: Незаконне привласнення особою знайденого або чужого майна, щзо випадково опинилося у неї (ст. 193).

Якісно-означальні прислівники незаконно, технічно, радіоактивно поєднуються 3 дієприкметниками і виражають якісну ознаку іншої ознаки: Незаконне виготовлення, підроблення, використання або збут незаконно виготовлених, одержаних чи підроблених марок акцизного збору чи контрольних марок (ст. 216); Випуск в експлуатацію технічно несправних транспортних засобів або інше порушення їх експлуатації (ст. 287); Заготівля, перероблення або збут радіоактивно забруднених ○ О. Ю. Прадід, 2013. 
продуктів харчування чи іншої продукції (ст. 327).

У назві ст. 239-2 прислівник особливо поєднується з прикметником і виражає безвідносно велику міру вияву ознаки: Незаконне заволодіння землями водного фонду в особливо великих розмірах.

Висловлені вище міркування дають підстави резюмувати: 1. У назвах розділів і статей ККУ найуживанішими після іменників $\epsilon$ прикметники (26 прикметників проти 127 іменників у назвах розділів, 568 прикметників проти 1994 іменників у назвах статей), більшість із яких - відносні; 2. Найчастіше прикметники, ужиті в назвах розділів і статей кодексу, утворені за словотвірними моделями ОІм. + -н-, ОІм. + -ов-, ОІм. + -ськ-; 3. Рідко в назвах розділів і статей ККУ фіксуються займенник (відповідно 6 і 61 раз), ще рідше - числівник (3 рази лише в назвах статей) і прислівник (11 разів - лише в назвах статей).

\section{Література}

1. Білоусова О. І. Граматична специфіка мови українського законодавства : дис. ... канд. філол. наук : 10.02.01 - українська мова / О. І. Білоусова. - Дніпропетровськ, 2010. $-215 \mathrm{c}$.

2. Кравченко С. П. Мова як фактор правоутворення та законотворення : автореф. дис. ... канд. юрид. наук : 12.00 .01 - теорія та історія держави і права; історія політичних і правових вчень / С. П. Кравченко. - Одеса, 2000. -20 с.

3. Прадід О. Ю. Словотвірні та граматичні особливості назв розділів і статей Кримінального кодексу України : автореф. дис. ... канд. філол. наук : $10.02 .01-$ українська мова / О. Ю. Прадід. - Дніпропетровськ, 2013. - 20 с.

4. Рогожа В. Г. Засоби вираження вольової модальності в текстах кодексів України : автореф. дис. ... канд. філол. наук : 10.02.01 - українська мова / В. Г. Рогожа. - К., 2005. $-24 \mathrm{c}$.

5. Тростюк 3. А. Понятійний апарат Особливої частини Кримінального кодексу України : автореф. дис. ... канд. юрид. наук : 12.00 .08 - кримінальне право та кримінологія; кримінально-виконавче право / 3. А. Тростюк. - К., 2000. - 16 с.

Стаття надійшла до редакції 18.11.2013 p. 